\title{
Gendered Activity and Jesus's Saying Not to Worry
}

\author{
Janelle Peters \\ University of Chicago
}

\begin{abstract}
The flowers' activity in the saying of Jesus about anxiety indicates an interest in cloth production across the socio-economic spectrum. I demonstrate that wool-working is a central feature of the multiform tradition of this saying and that spinning in particular was associated with women. I further note that the activity of gazing at flowers was an activity that was connected with the iconography of the goddess Spes, the Roman personification of Hope. These two cues render the entire saying an exhortation toward the feminine.
\end{abstract}

\section{Key Terms}

Q 12:22b-28; Luke 12:22b-28; Matthew 6:25-30; P. Oxy. 655; Coptic Gospel of Thomas; saying of Jesus; flowers; spinning; carding; clothing; creation; women; Spes

\section{$1 \quad$ Introduction}

Textile production appears in the history of reception of Jesus's saying about worry, as Spenser's lines from The Faerie Queene (1590) on the lily suggest:

Yet neither spins, nor cards, ne cares nor frets,

But to her mother nature all her care she lets. ${ }^{1}$

Certainly, the earliest traditions about Jesus's words on anxiety centre on clothing and its manufacture. This article considers the examples from nature related to clothing that comprise Jesus's exhortation not to worry found in Q, Luke, Matthew, P. Oxy. 655 (the Greek version of Gos.

\footnotetext{
1 See Petty-Fitzmaurice (1830, 28).
}

Neotestamentica 50.1 (2016) 35-52

(C) New Testament Society of Southern Africa 
Thom. 36.1-4), and the Coptic manuscript of the Gospel of Thomas Nag Hammadi Codices II (II,2, Gos. Thom. 36). ${ }^{2}$

Q 12:22b-28:

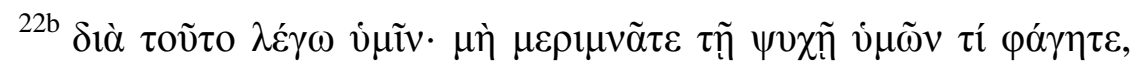

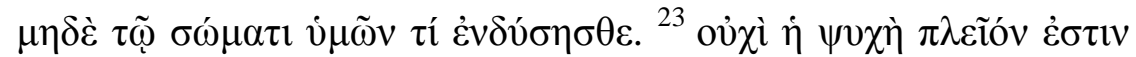

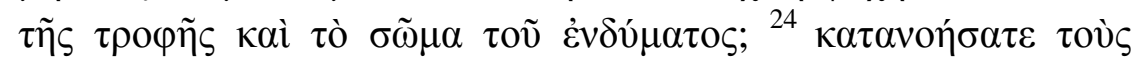

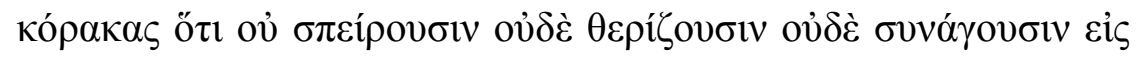

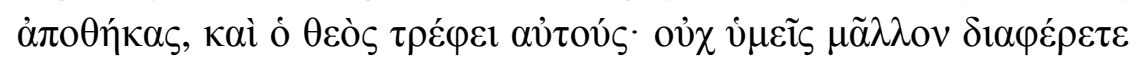

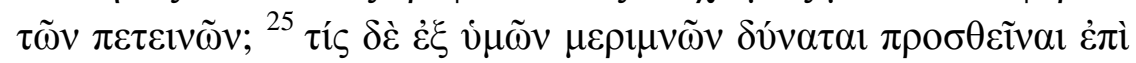

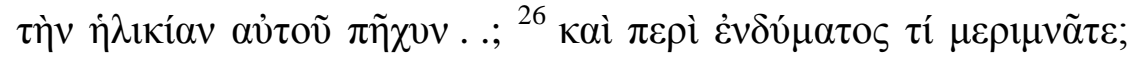

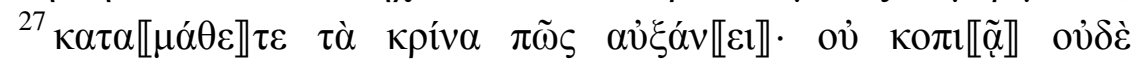

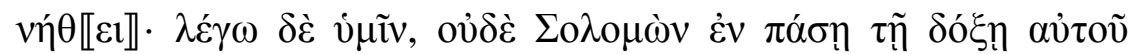

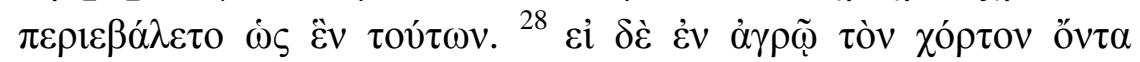

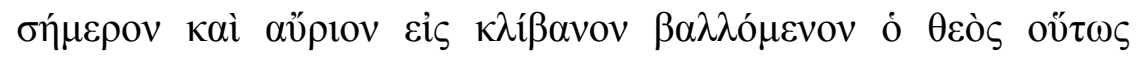

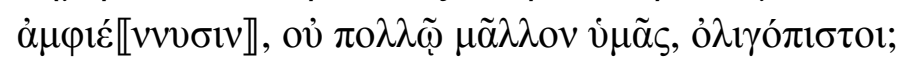

${ }^{22 b}$ Therefore I tell you: Do not be anxious about your life, what you are to eat, nor about your body, with what you are to clothe yourself. ${ }^{23}$ Is not life more than food, and the body than clothing? ${ }^{24}$ Consider the ravens: They neither sow nor reap nor gather into barns, and yet God feeds them. Are you not better than the birds? ${ }^{25}$ And who of you by being anxious is able to add to one's stature a . cubit? ${ }^{26}$ And why are you anxious about clothing?

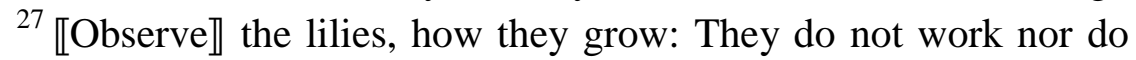
they spin. Yet I tell you: Not even Solomon in all his glory was arrayed like one of these. ${ }^{28}$ But if in the field the grass, there today and tomorrow thrown into the oven, God clothes thus, will he not much more clothe you, persons of petty faith! ${ }^{3}$

Luke 12:22b-28:

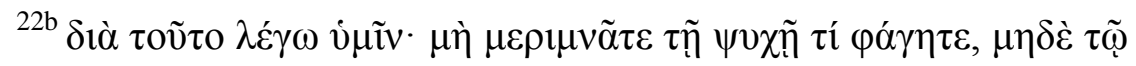

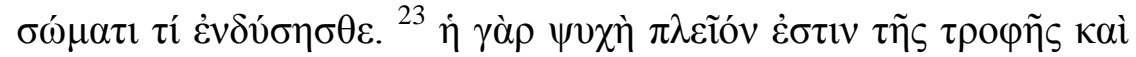

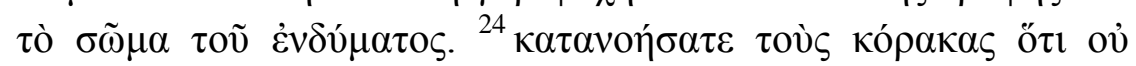

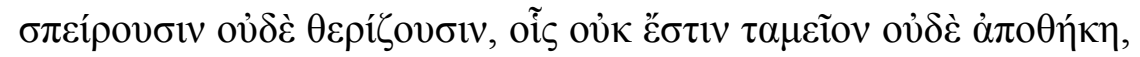

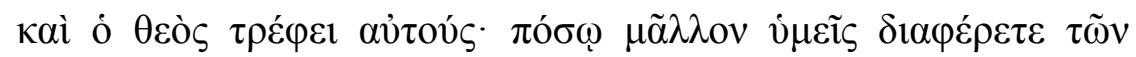

2 While P. Oxy. 655 has often been taken as a Greek version of Gos. Thom., the later Coptic version lacks much of the saying; see Gathercole $(2014,357)$.

3 See Robinson, Hoffmann, and Kloppenborg (2002, 122-123). 


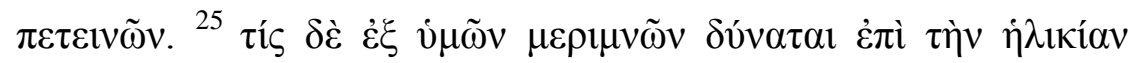

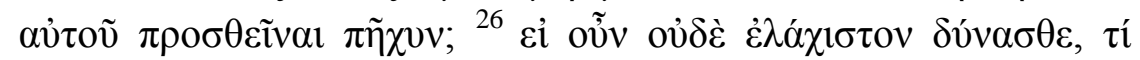

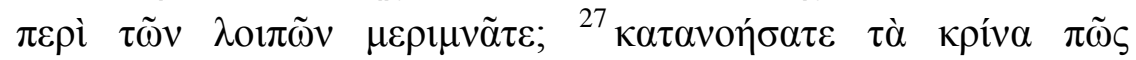

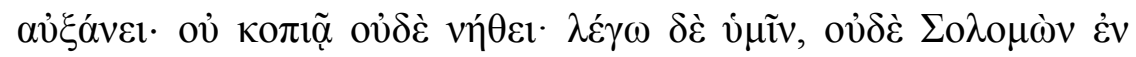

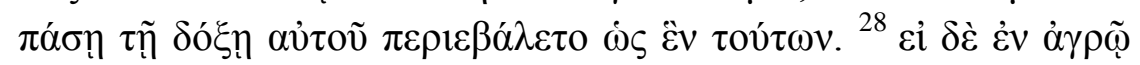

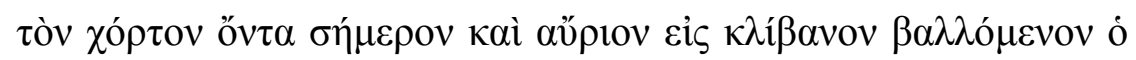

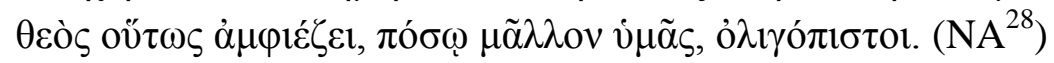

${ }^{22 b}$ Therefore I tell you, do not worry about your life, what you will eat, or about your body, what you will wear. ${ }^{23}$ For life is more than food, and the body more than clothing. ${ }^{24}$ Consider the ravens: they neither sow nor reap, they have neither storehouse nor barn, and yet God feeds them. Of how much more value are you than the birds! ${ }^{25}$ And can any of you by worrying add a single hour to your span of life? ${ }^{26}$ If then you are not able to do so small a thing as that, why do you worry about the rest? ${ }^{27}$ Consider the lilies, how they grow: they neither toil nor spin; yet I tell you, even Solomon in all his glory was not clothed like one of these. ${ }^{28}$ But if God so clothes the grass of the field, which is alive today and tomorrow is thrown into the oven, how much more will he clothe you-you of little faith! (NRSV)

Matthew 6:25-30:

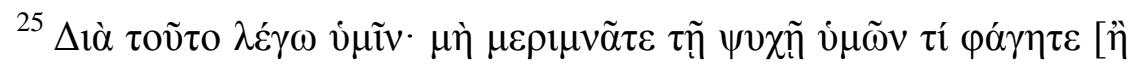

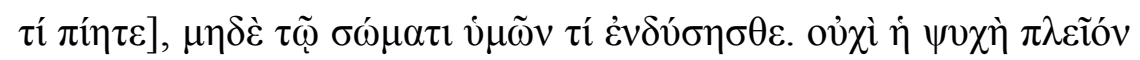

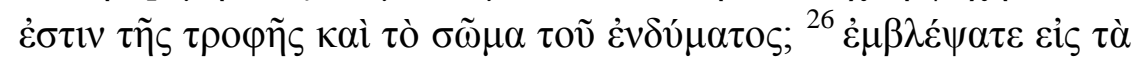

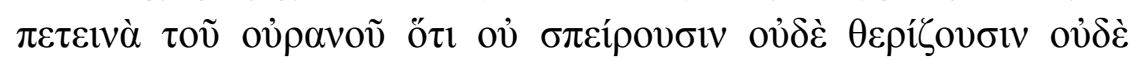

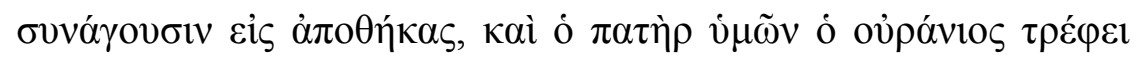

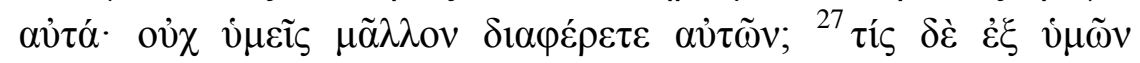

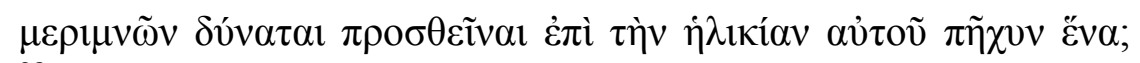

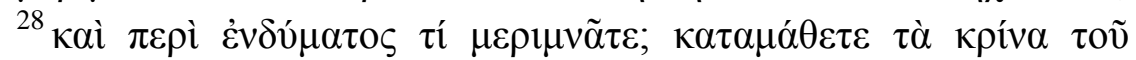

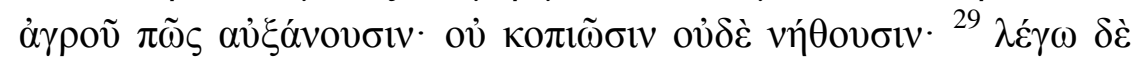

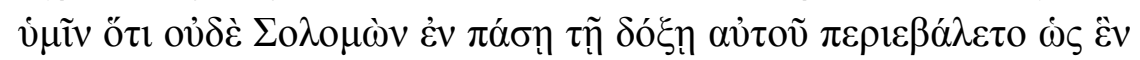

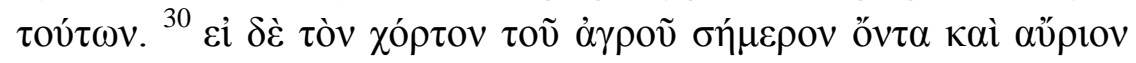

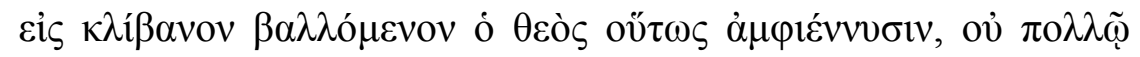

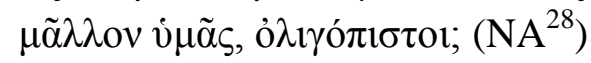

${ }^{25}$ Therefore I tell you, do not worry about your life, what you will eat or what you will drink, or about your body, what you will wear. Is not life more than food, and the body more than clothing? ${ }^{26}$ Look at the birds of the air; they neither sow nor reap nor gather 
into barns, and yet your heavenly Father feeds them. Are you not of more value than they? ${ }^{27}$ And can any of you by worrying add a single hour to your span of life? ${ }^{28}$ And why do you worry about clothing? Consider the lilies of the field, how they grow; they neither toil nor spin, ${ }^{29}$ yet I tell you, even Solomon in all his glory was not clothed like one of these. ${ }^{30}$ But if God so clothes the grass of the field, which is alive today and tomorrow is thrown into the oven, will he not much more clothe you-you of little faith? (NRSV)

P. Oxy. 655, i.1-17 (Gos. Thom. Logion 36):

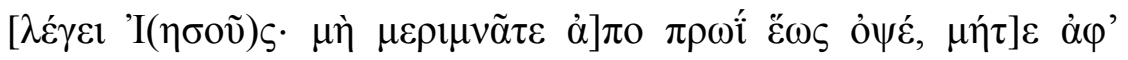

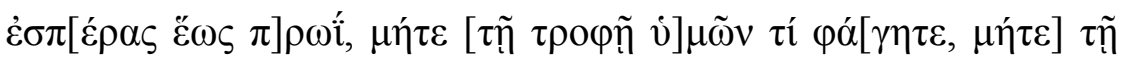

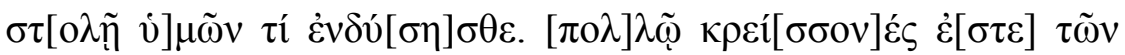

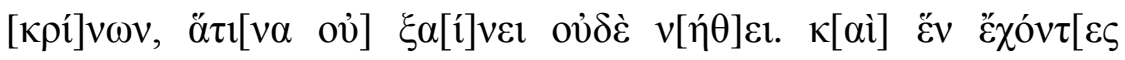

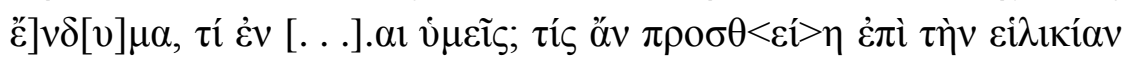

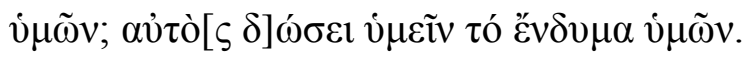

[Jesus says, "Do not be anxious] from dawn [to late, nor] from eve [to] dawn, either [about] your [food], what [you are to] eat, [or] about [your] robe and what you [are to] clothe yourself in. [You are] far better than the lilies, which do not card nor spin. [And] having one clothing, ... you ... ? Who might add to your stature? That one will [give] you your clothing!” (Robinson 2005, 883)

NHC II, 2.39.24-27 (Gos. Thom. Logion 36):

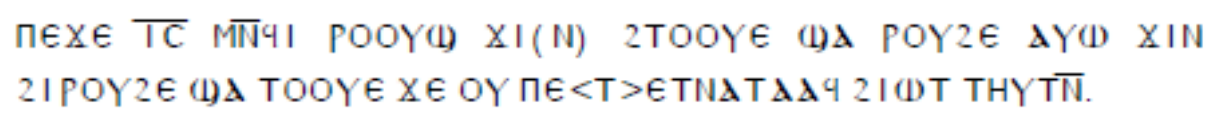

Jesus said, "Do not be anxious from morning until evening and from evening until morning about what you will wear." (DeConick 2006, 149)

For Matthew and Luke, Jesus speaks to those "of little faith," engaging in a critique of Graeco-Roman cultural norms. Johnson and Tannehill (2010, 475-490) identify the cultural norms against which this saying argues as those that established an honourable woman. In Matt 6:26 and Luke 12:24, Jesus instructs his disciples to observe how the birds neither sow nor reap. The injunction to "consider the lilies" in Matt 6:28 and Luke 12:27 is necessary for the first part of the subsequent verse of 
God clothing the grass of the field. Death and Hades are alluded to in the second part that observes that God performs this action of clothing for even the grass which is in the field today and in the oven tomorrow. This, as Johnson and Tannehill $(2010,480)$ have noted, casts God in the female occupation of cloth production. I will consider the saying's treatment of flowers, which coincides with Seneca's philosophical conclusions from flowers and with the steadily burgeoning imperial emphasis on the goddess Spes, the personification of Hope, whose iconography featured her gazing intently at her flower of fecundity. I will suggest that the gospels allow their audiences both to understand God in contemporary syncretistic ways and to be confounded by the ways that God surpasses contemporary syncretistic expectations. Though the goddess Spes does not make it into the Christian tradition, humans replicate her divine activity of gazing at flowers.

\section{$2 \quad$ Jesus's Saying about Flowers}

The conclusions Matthew and Luke draw from the saying differ slightly. In Matthew, Jesus commands his disciples to observe how the "birds of the air" do not reap and the "lilies of the field" do not spin, and implies that therefore God will provide much more for them. This instruction is part of Jesus's Sermon on the Mount, and it occurs after an admonition that the "lamp of the body is the eye" (6:22). Matthew's redactional changes imply that the eye should see creation. Matthew uses "birds of the air" ( $\tau \dot{\alpha}$

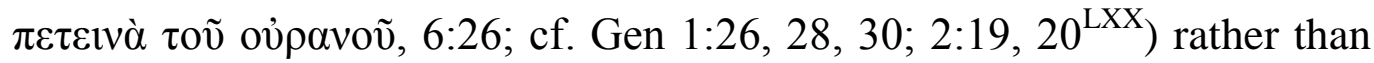

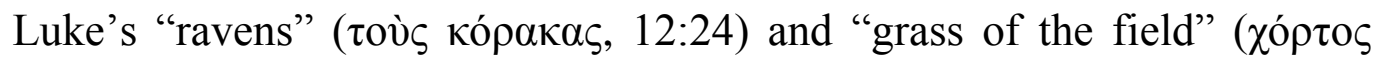

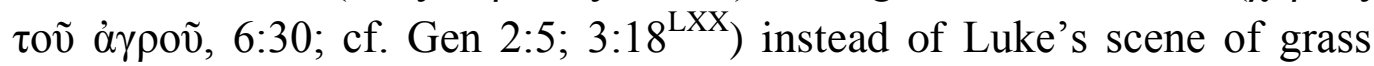
being "in [a] field" ( $\dot{\varepsilon} v \dot{\alpha} \gamma \rho \tilde{\varphi}, 12: 28)$ rather than belonging to it. These changes imply a backdrop in Gen 1-3 (Dillon 1991, 621). Mealand (1980, 179-184), noting the creational elements in Q 12:22b-31, observes that the eschewal of work in the passage disregards the etiology of labour provided by Genesis, which claims that the sweat of the brow is a result of the expulsion from the Garden of Eden. Matthew, like the Stoic-influenced author of 1 Clement (19.2-3) suggests that humans may again rely on divine providence.

In Luke, this passage does not occur in the Sermon on the Plain but in ch. 12. Luke employs the passage about the birds and flowers as the positive follow-up to the Parable of the Rich Fool that describes how a wealthy man dies before he gets to enjoy his accumulated wealth. Rather than worry about inheritances, one should worry about storing one's 
treasures in heaven. Luke's reference to ravens plays off the birds' association with impoverished prophets who must rely on divine providence. Strabo records the story that Heracles was guided by two ravens on one occasion (Geogr. 17.1.43). In $1 \mathrm{Kgs} \mathrm{17,} \mathrm{Elijah} \mathrm{relies} \mathrm{on}$ ravens for his food supply during a drought appointed by the Lord, but then he promises a widow about to cook her last meal for her and her son that their grain and oil will last until the end of the drought. The mendicancy of ravens is evident in their mating: when ravens reproduce, they essentially replicate, and one couple moves on to another metropolis because there can only be two ravens in a place at any one time. ${ }^{4}$

Despite their editorial changes to make their source story $(\mathrm{Q})$ consistent with their gospels, both Matthew and Luke present the epideictic function of the birds and flowers to show that God will provide for his anxious disciples just as he attends to the plants and animals, which are without the inclination to worry. This conclusion is omitted in the noncanonical versions of this saying, which focus on the garment that God will give, and not the transitory quality of life. P. Oxy. 655 mentions stature as a provision of God along with the garment. It is possible there is a metaphorical quality to the reference to stature, particularly given the legislated relationship between garments and social status in the Roman Empire.

The logic of the Q passage that underlies the versions of Matthew and Luke contradicts the tendency of wisdom literature to suggest that hard work and diligence naturally result in earthly rewards. ${ }^{5}$ God will not only provide for the harvest on behalf of the birds and for the clothproduction on behalf of the lilies, he will also clothe the grass of the field, thus taking the result of spinning - cloth-production - and bypassing the work of the birds by clothing the grass they might have reaped. To Johnson and Tannehill (2010, 490), this Q exhortation represents a challenge for men and women to step away from the socially and economically rewarding modes of production in the first century. The economic component is much more developed in Luke, perhaps not surprising with the mention of female cloth merchants in his subsequent work, Acts, whereas the moral component is much more developed in Matthew, perhaps not surprising given his advocacy of eunuchs for the kingdom.

\footnotetext{
4 Pseudo-Aristotelian, [Mir. Ausc.] 842b 5-9, 844b 7-10; Antigonus, Hist. Mirabilium 15; Pliny the Elder, Nat. 10.15; Aelian, Nat an. 7.18.

5 On this tendency see O'Connor $(1990,54)$.
} 
Many interpreters see the birds and flowers as forming a malefemale gendered pair. ${ }^{6}$ Gendered pairing is a common feature of the $\mathrm{Q}$ collection and the synoptic gospels. Fricker $(2004,101)$ identifies seven mixed pairs in the gospels and sees them as a hallmark of the historical Jesus: Mark 2:21-22; Q 13:18-21; Q 12:24, 27-28; Q 17:34-35; Luke 15:3-10; Q 11:31-32; Luke 4:25-27. The saying about the lilies and the birds, then, is also one of these gendered pairs. The item about the "birds that neither sow nor harvest" refers to the masculine agricultural activity; the lilies that do not spin is thought to refer to the feminine activity of wool-working. While Schottroff $(1995,5)$ expresses concern that the identification of women with spinning reifies women's confinement to the home, Gundry (2002, 159-180) argues that the "tidiness" of assigning ravens to masculine activity and lilies to feminine activity does not necessarily find corroboration in the $\mathrm{Q}$ passage. Gundry points to the difference between "Consider ... that" (Q 12:24) and "Observe ... how" (Q 12:27). He thinks that Jesus understands both men's and women's work as involved in the production of clothing, broadly construed as "toiling and spinning" in the Q tradition. I will argue that Jesus includes spinning as an activity often performed by women, but he does not relegate women to it. Both men and women may look to the lilies for reassurance that divine goodness remains present in creation, even without labour or activity on the part of creation.

The flowers are thought to be more fundamental to the original saying, particularly given the omission of the fowl in P. Oxy. 655 (col. i.117) and NHC II 2.39.24-27. Robinson and Heil (2001, 1-25) argue that P. Oxy. 655 represents a form of the saying older than the $\mathrm{Q}$ version. Gundry $(2002,180)$ concludes that P. Oxy. 655 could be a redaction of Q, which implies that the flowers were perceived to be essential in the epitome of the saying if not alone in the oldest form of the saying. ${ }^{7}$ While there is some debate about the relationship of $P$. Oxy. 655 to the sayings tradition, that Jesus or his earliest sayings source talked about flowers seems credible to most textualists (see Porter 2001, 84-92).

Even without the consistent and straightforward way with which P. Oxy. 655 presents Jesus's teaching about flowers and worry, the emendations that Matthew and Luke make seem to point to a composition

\footnotetext{
6 See Luz (1985, 368-369); Dillon (1991, 619); Schottroff (1995, 350); Carter (2000, 177-178); Kloppenborg (2000, 97); Klein (2006, 454); Johnson and Tannehill (2010, 475-476).

7 Gundry's position has been adopted broadly. See, for example, Autero $(2016,194)$.
} 
time after the fall of Jerusalem and its temple. The reference to Solomon could be seen as being included by Matthew and Luke in order to reassure their audiences that the sacking of the second Jewish temple in Jerusalem by the Romans did not abrogate the Jewish relationship with God. Solomon, after all, was credited for the construction of the first Jewish temple there. Jesus's sayings elsewhere do not allude to historical figures from Scripture, so it is more likely that the reference to Solomon was introduced into the traditions about the historical Jesus after the fall of the second temple.

The historical Jesus would probably have uttered words that focused on the lilies that do not spin. Without the need for fields and agricultural production to contrast with the destruction of temples and their cities, the saying is one about the wool-working of the flowers and not about the ephemeral and yet beautiful nature of their growth (Matt 6:28, “. . . $\pi \tilde{\omega} \varsigma \alpha \hat{\xi} \xi \alpha \dot{v} 0 v \sigma ı v ")$. The reconstructed text of P. Oxy. 655 not only has

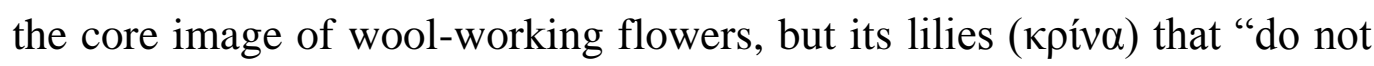

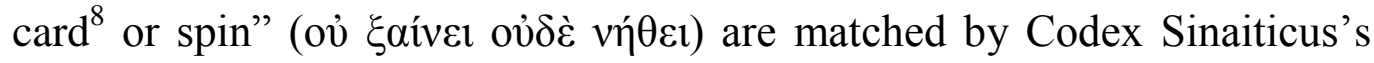
erased reading of Scribe A, who tends to have knowledge of alternate textual traditions. ${ }^{9}$ The logic of this passage matches that of Matt 7:11 and Luke 11:13, where Jesus says that God is a better father than the evil parents on earth who nonetheless give good gifts to their children. ${ }^{10}$ Like any teacher seeking to reiterate a central message, the earliest traditions portray Jesus giving the same instruction on the goodness of God and the wisdom of trusting in that goodness by giving his disciples multiple

${ }^{8}$ Carding is the process by which fibers are opened, cleaned and straightened in preparation for spinning.

9 Robinson and Heil $(2001,1-25)$ discuss the unlikelihood that both the erased reading of Scribe A of Codex Sinaiticus at Matt 6:28b and P. Oxy. 655 independently attest "they do not card," a position originated by T. C. Skeat. For earlier readings of "card" without the use of Sinaiticus, see the review of Glasson (1962, 331-332). Among the notable earlier emendations was the reading of Michelsen in 1909 on the basis of the Western variant to Luke 12:27. Nonetheless, despite these convergences, there might not have been a singular tradition of this Jesus saying. DeConick $(2005,59)$ argues for oral multiforms of this particular saying. Indeed, Gathercole $(2014,361)$ follows Jongkind (2006) in ascribing this variant to Scribe A's penchant for "non-canonical" traditions. Without more manuscripts, whether the unstable term "carding" appeared with the stable term "spinning" in the original tradition cannot be definitively proven, particularly as Jesus was presumably not speaking in Greek..

${ }^{10}$ Jacobs-Malina $(1993,2)$ talks about Jesus as playing the female role of the "wife of the absent husband." 
reassurances of how little humans need to do to warrant such divine favour.

\section{Flowers That Do Not Work}

What labour the flowers do not perform has been the topic of much debate. According to P. Oxy. 655 and its possible version of Gos. Thom. 36, the flowers "neither card nor spin." Certainly, the saying's terse appearance in the Coptic NHC II 2.39.24-27 commends an interpretation that would prioritise cloth production over farming of raw materials for cloth production in both the time of potential worry (night and day) and the subject of worry (one's clothes). Robinson and Heil $(2001,16)$ argue that P. Oxy. 655 i.1-17a represents an earlier tradition than Q 12:22b-31 or its canonical derivatives, Luke 12:22b-31 and Matt 6:25-33. They wish to emend the positive "grow" in Q to another negative, so that the lilies neither card nor toil nor spin. This construction of the lilies, they claim, would better parallel with the triple negative of the ravens that "neither sow nor reap nor gather into barns." The canonical formulation has three verbs for the lilies, but one describes what the lilies do ("grow") while the others describe what the lilies do not do ("toil and spin"). Robinson and Heil (ibid.) argue that the occurrence of only two verbs in P. Oxy. 655, "neither card nor spin," indicates that "in this part of the tradition the paralleling problem that was called forth by the pair of illustrations in $\mathrm{Q}$ was indeed lacking." This is a rather confusing explanation of the received texts as it posits that it is not P.Oxy. 655 that has inserted card into the tradition, but the canonical tradition that has inserted the parallels and not preserved them as corresponding parallels. In other words, Luke inserted both the ravens and the verb "grow" for the lilies.

As Johnson and Tannehill (2010, 482-489) have noted, the otherwise bizarre image of wool-working flowers makes sense if the flowers are read as female. Wool-working was a particularly feminine activity. It had special significance in the ancient image of the honourable woman across the social spectrum. In Livy's History, wealthy Lucretia's merit was proved by her weaving late into the night (1.57). ${ }^{11}$ In Plutarch's Bravery of Women (Mulier. virt.), Aretaphila saves Athens and then retreats to a quiet life at her loom instead of accepting the governance of

\footnotetext{
${ }^{11}$ There were several early imperial accounts of Lucretia, but Livy's deals most with the issue of her consent. For a study that links this with legislation concerning sexual consent, see Moses (1993, 38-83).
} 
the polis proffered by the grateful citizenry (257E). An annual event in Athens - the Panathenaia - celebrated the origin of the city, order from disorder, and civic unity. Part of the ceremony was the weaving of a new $\pi \varepsilon \dot{\pi} \lambda \mathrm{s}$ (decorative tunic) by selected girls and women for Athena. Even the Roman Stoic, Musonius Rufus, in That Women Too Should Study Philosophy, argues that philosophical study will improve the industriousness of women, not replace it $(2005,51)$. In the Protevangelium of James Mary is chosen as one of seven virgins who will weave a veil for the temple of the Lord. She receives the lot to weave the most holy colours of purple and scarlet (Prot. Jas. 10.1-12.1). The symbolic nature of the production of cloth has also been noted by Coon (1997, 41-44), who notes that spinning and weaving signify women's devotion to asceticism.

Interestingly, the Jesus of Matthew, Luke, and $Q$ refers to the raiment of Solomon. Surely, this would have been a comfort to men that idle wives would not have reduced their stature in the community, since the clothes of the flowers that do not spin are said to be more glorious than those of Solomon. But the lack of a reference to Solomon present in $P$. Oxy. 655 suggests that the concern of the Jesus saying fell more on the activity of the flowers than on their clothing.

\section{$4 \quad$ Spinning in the Ancient Context}

The verb used in both Matthew and Luke is not weaving but spinning. Moreover, the textual variants of Matthew in the Greek Oxyrhynchus Papyri and the Codex Sinaiticus insert carding rather than weaving, thus continuing to suggest the process of making yarn rather than that of weaving it. The role of spinning in the ancient Mediterranean context of Jesus's saying should be investigated.

The spindle was connected with women and women goddesses, including Athena. Roman brides had spindles as one of their wedding-day accoutrements, though Pliny observed country customs held that an uncovered spindle could harm the harvest. ${ }^{12}$ Representations of Athena Ergane holding a spindle continued in the Roman period. Pausanias said that the Athena of Erythrae held a spindle in each hand (Descr. 7.5.9), though this was probably a distaff and a spindle. The imperial coins of Athena of Ilium probably show the same scene (Brendel 1977, 59).

Several spindles have been found from the Roman period during and around the time of Jesus's ministry in excavations in Israel. Yodefat's

\footnotetext{
${ }^{12}$ Pliny the Elder, Nat. 8.194; 28.29; See Hersh $(2010,162)$.
} 
houses, destroyed in the First Jewish Revolt, yielded over 250 pyramidal loom weights $(10-15 \mathrm{~cm}$ in height). The difference may suggest differing reliance on cloth production in the economies of Galilean cities. However, spinning equipment has also appeared in the context of gendered necessities for the maintenance of the customs of Roman Jewish daily life. Archaeologists uncovered approximately 90 loom weights at Gamla (Aviam 2013, 27). From the Cave of Horror and the Cave of Letters, used by Jewish refugees during the Bar Kokhba Revolt, have come wooden combs, mirrors, spindle whorls, and textiles (Hachlili 2005, 27).

In the Roman period, an association of spinning women with being industrious in the bedroom as well seems to have persisted from earlier periods. Women carried spindles in Roman bridal processions. The sight of Lucretia spinning so inflames the lust of a royal male in Livy's History that he rapes Lucretia and causes a civil war (Peskowitz 1997, 70). The spindle features to show Leucothoe's forcible removal from chaste womanhood in Ovid's Metamorphoses (Metam. 4.228-233). A case history presented by Hippocrates (Epid. 5.25) describes a sixty-year-old woman who had experienced labour pains throughout her life; this woman went through birth pangs and bore a rock resembling the whorl of a spindle. Ephesian Artemis was known not only for her fertility but also for her golden spinner, and a female spinner figure has been found in her sanctuary (Brendel 1977, 61).

In the Tosefta and Talmud, spinning's indication of sexual promiscuity is more strongly suggested. As Baker (2002) points out, the Talmudic rabbis "provide an explicitly sexual narrative for" the phrase "spinning in the shuk [marketplace]":

Said Rabbi Judah in the name of Samuel, "It refers to a woman who shows off her arms to bypassers." Said Rabbi Hisda in the name of Abimi, "It refers to a woman who spins [so that the spindle] dangles toward her vulva [literally 'face']." ... Said Rabbah bar bar Hannah, "Once, I was walking behind Rabbi Uqba. I saw an Arab woman sitting, plying her spindle and spinning [so that the spindle] dangled toward her vulva [literally 'face']. When she saw us, she broke off [the thread] and dropped the spindle and said to me, "Young man, would you fetch me back my spindle?" (p. 102)

In directing disciples away from spinning and toiling, Jesus eschews the normal economic production through textile work expected of 
women in texts from Proverbs to rabbinic literature, as Johnson and Tannehill have so eloquently suggested (2010, 475-490). He also removes his listeners from economic participation in prostitution. In Mark 6:14-29 and Matt 14:1-12, the daughter of Herodias dances in front of men in return for compensation of her own choosing, leading her to select the payment her mother wishes: the head of the man who questioned the validity of her mother's marriage, John the Baptist. The lilies that neither card nor spin should be seen as encompassing both honourable women and those suffering from some social and legal disability, whether prostitutes, innkeeper's wives, barmaids, or household slaves (McGinn 2004, 16). Jesus's God is one who does not require that women work-sexually or otherwise-for their salvation.

\section{$5 \quad$ Hope as a Feminine Activity}

In taking away the feminine symbol of an honourable woman spinning at home or the fallen woman spinning in the marketplace, Jesus also invokes a feminine activity of considering the lily, receptively gazing, in a positive, prescriptive manner. Considering the lily is not an areligious activity in the Roman Empire; it is what the goddess Spes does on coins flung all across the Mediterranean. Given Luke's reference to Solomon's temple, it would seem that not only is Jesus critiquing imperial industry of farming and spinning, but he is pointing out that the Roman ideals include such antithetical figures to toil as flower-gazer Spes, who has her own cult and temples, and that these ideals have their own Jewish antecedents. God the Father provides true Spes, not the Emperor, whether Claudius or Vespasian.

Spes was a thoroughly Roman deity, but she had a Greek counterpart: Elpis. Elpis was the only gift from the gods to remain in Pandora's box when curiosity got the better of her, in the account known from Hesiod's Works and Days (Op.). Presumably, if Elpis resembled the evils in the box that flew out immediately, she would be a winged creature. However, Elpis's confinement in the jar parallels the domesticity of Pandora and women, so it is difficult to speculate about her wings. Momigliano (1987, 75) notes that hope could have some sinister connotations in the Classical period, becoming "plainly a bad thing" in Theognis 1.637 and in Euripides's Suppliants (Suppl. 479). Vernant (1989, 83) ascribes the polar aspects of Elpis to the polarity inherent in divinities such as Eris and Nemesis. The reference to good Elpis-found from Hesiod to the Roman period-implies a bad Elpis exists. Moreover, 
Elpis's role is ambiguous in that her main beneficial quality may be illusory: in Aeschylus's Prometheus Bound (Prom.), the Titan boasts, "I have delivered mortals from the foreknowledge of death that is called elpis" (Vernant 1989, 82).

There was no official cult of Hope in Greek cities, but she is found as a goddess accompanied by Nemesis on the Hadrianic Neo-Attic crater, now part of the Chigi collection, and by herself on the coins of cities such as Alexandria (Momigliano 1987, 75). Another object from the early Roman period, a limestone mould bearing Elpis and Nemesis, acquired by the British Museum, presents Elpis almost in the attitude of the normal Spes type. She holds out a flower in her right hand and grasps her skirt and chlamys with her left arm. It is the grasping of the chlamys in addition to the skirt that is the modification. Bracelets encircle her wrists, and a diadem crowns her hair. Below her are a wreath and palm, symbols normally associated with Nike/Victoria.

In any event, Pandora, the first woman, was also the finder of hope according to Greek mythology, and she has a prerogative on hope, good, and evil also found in the gospels. Pandora's fashioning by the gods is prominently depicted on the Parthenon, serving as the base of the colossal statue of Athena Parthenos. ${ }^{13}$ Pausanias's discussion of the Athena Parthenos, like his discussion of other monumental sculpture, connects the visual representation to Greek mythology of Pandora. Rather than reading the image in light of its various parts, for Pausanias, the visual image of the Athena Parthenos serves to remind one of the myth of the first woman (Elsner 2007, 248). Often Pandora is depicted as a jar. In such a representation, there could be an allusion to Zeus's two jars-one good, and the other evil-from which a person receives his or her life's allotment. Both Pandora's jar and Zeus's jars indicate that a person may receive a mixed portion of good and evil or all evil. There is no possibility of all good (Il. 24.527-533). This worldview may be discerned in Matthew's account of Jesus's exhortation not to worry. There, Jesus concludes with the observation that even the pagans seek clothing and shelter, so God knows that his adherents need such things. Accordingly, believers should concern themselves with today, as "sufficient for a day is its own evil."

\footnotetext{
${ }^{13}$ The statue and its pedestal are no longer extant, but there are descriptions by Pausanias and Pliny as well as copies of the Athena Parthenos from Pergamon. There is also the small, unfinished Lenormant statuette of Athens's Athena Parthenos.
} 
The Roman goddess Spes, in contrast to Elpis, was an actual embodiment of an abstract quality who received her own official cult image and temples. Worship of Spes as a deity occurred concomitantly with her invocation as a catchword like libertas and as a concept. In a foundation essay on Roman virtues, Mattingly (1937, 107) cleverly summarises the differences between the gods of the pantheon, who have lives and personal relationships with each other, and the deities of abstract concepts, who have no back stories: "They do not marry and are not given in marriage; they have, in fact, no personal relationships of any kind to one another. In the Roman world of thought, Righteousness and Peace have not kissed each other." The resonance of the Virtues with angels, Mattingly posits, facilitated their transfer from pagan religion into Christianity as it developed (ibid., 117).

In Rome and environs, Spes had her own temples. On coins, she is usually shown as an archaic Kore advancing as she bears a flower in her raised right hand, while holding up the hem of her dress with the lowered left hand. Her temple in Rome was located in the Forum Holitorum, the vegetable market between the Capitoline and the Tiber, and it was near both the port and the early part of the triumphal route. ${ }^{14}$ The Temple of Spes burned down a second time in the year $31 \mathrm{BCE}$, at the beginning of Augustus's reign. Germanicus rededicated the Temple of Spes in 17 CE. ${ }^{15}$ Its ruins are usually identified as the southernmost Doric temple of San Nicola in Carcere (Popkin 2016, 191).

Spes could also serve as a tutelary deity to other deities. The multiple associations of Spes can be seen in Plautus's mention of Spes along with Salus and Victoria (Mercator 867). It is possible the cult deity of Concordia (Roman goddess of Harmony) lifted her left elbow above an archaistic Kore or Roman Spes. Tiberius, before he became emperor, restored the temple of Concordia in $10 \mathrm{CE}$ and issued an orichalcum sestertius (brass coin) featuring the temple on its obverse (35-37 CE). Imperial coins of Hadrian and Antoninus Pius help supply more details. The Roman viewed Concordia seated, a patera in her right hand and a Kore or Spes beneath her left, through the portals behind the hexastyle portico. Concordia held a cornucopia in her left hand or had it placed against the left side of the chair (Vermeule 1957, 284).

\footnotetext{
${ }^{14}$ Spes appears, moreover, to have had another shrine in the east of Rome, known as Spes Vetus.

${ }^{15}$ Tacitus, Ann. 2.49.
} 
Roman virtues, according to Cicero's On Laws (Leg.), were categorised between virtutes and res expetendae (2.28). Concordia belonged to the former category, Spes to the latter. The combination of a virtue and a desired state reflects the conflation that often occurred with individual qualities and the fluidity of the taxonomy. Moreover, as Wallace-Hadrill $(1981,309)$ notes, a quality like Salus is more than a res expetenda. The quality of Salus, when attached to the emperor represents the virtue, the desired state and the power to bestow the desired state upon others as a benefaction: "Salus Augusti is not just the Safety of the ruler, but the Saving Power that flows from him."

Spes was of fundamental importance for the early Roman Empire, beginning with Emperor Augustus. In the early imperial age, Livy associates the rebuilding of her temple in 212 BCE with an emphasis on Roman religio, following the defeat of the Roman armies to Hannibal. Livy's investment in Spes is on par with the interest of Dionysios of Halicarnassus in the story of Evander and his Arcadians founding the temple of Victoria, which proved for him that "Rome" was "Greek" (Clark 2007, 63). Livy tells us that in order to restore confidence in Roman gods and cult, the Senate banned foreign cults within the city and appointed two commissions, one to conserve temple treasures neglected because of the war and one to rebuild the temples of Fortuna, Mater Matuta, and Spes. All three temples had been of some antiquity, had burned the previous year, and had housed deities who were thoroughly Roman. ${ }^{16}$ In the provinces, a coin bearing the reverse legend Spes Coloniae Pellensis, was issued at Pella in $16 \mathrm{BCE}$ and implies that Augustus was "the Hope of the Colony of Pella." The colony consisted of Roman veterans, some of whom had fought at Actium, but it is generally in agreement with the lavish praise of Augustus throughout the Greek East offered in the Priene inscription and so forth.

Public awareness of Hope's imperial importance would have been heightened by the rebuilding of the Temple of Spes in Rome by Germanicus in 17 CE. Germanicus's brother Claudius understood the rebuilding of Spes's temple as a major accomplishment. Claudius placed Spes on his coins because he wanted to commemorate the temple and to associate both the temple and the deity with his rule. Spes was depicted on a sestertius by Claudius in $41 \mathrm{CE}$ as Spes Augusta. Vespasian introduced a

\footnotetext{
${ }^{16}$ The temples of two of them, Fortuna and Mater Matuta, reportedly dated from the days of Servius Tullius. The Temple of Spes was built during the First Punic War.
} 
sestertius in $70 \mathrm{CE}$ with Spes Augusta offering a flower to the emperor and his two sons, Domitian and Titus. Titus abandoned both the Spes imagery and the title within two years, but Domitian retained them.

Given the ready Roman adoption and appropriation of existing cultural trends in the Mediterranean, the imperial eagerness to renew cults for hope, and fashion the Empire as the new hope, is hardly surprising. This emphasis on Spes and her iconography of gazing at a flower would have sustained the existing imagery on feminine hope from which it borrowed. Jesus's ministry and its preservation in sayings would have coincided with this intense Mediterranean interest in the traditional concept of hope. To consider the lilies is to engage in a womanly act of hope.

\section{Conclusion}

It is likely that the Greek-speaking audiences of the sayings of the historical Jesus did indeed have at least some contemporary cultural ideas of spinning and hope in mind when he talked about the birds, the flowers, and the people of little faith. Wool-working was an activity that was strongly correlated with female activity, and Jesus's audiences would have perceived it as such. I have argued that Jesus does not simply take away the feminine activity of work; he also encourages the feminine activity of contemplation, particularly that of flowers.

Roman iconography depicted Spes, the Roman goddess of hope, as a woman who gazed upon flowers. The ancient cult of Spes was revitalised in Augustan Rome through frescoes and elite literary production such as that of Virgil and Ovid. While perhaps not as prominent a figure as Victory on the Globe, Hope nonetheless would have been related to both Victory and Faith. With the fortunes of Spes on the rise throughout the empire, the Jesus saying on finding hope in the persistence of flowers would surely have been understandable wisdom. Yet, like so many cultural borrowings, Jesus's words call listeners back to the heart of the messagethe eternal good of God the Father provides for all creation-rather than let that message be appropriated for imperial propaganda.

\section{Bibliography}

Autero, Esa. 2016. Reading the Bible across Contexts: Luke's Gospel, Socio-Economic Marginality, and Latin American Biblical Hermeneutics. Leiden: Brill. 
Aviam, Mordechai. 2013. People, Land, Economy, and Belief in First-Century Galilee and Its Origins: A Comprehensive Archaeological Synthesis. Pages 5-48 in The Galilean Economy in the Time of Jesus. Edited by David A. Fiensy and Ralph K. Hawkins. Atlanta: SBL.

Baker, Cynthia M. 2002. Rebuilding the House of Israel: Architectures of Gender in Jewish Antiquity. Stanford: Stanford University Press.

Brendel, Otto. 1977. Symbolism of the Sphere: A Contribution to the History of Earlier Greek Philosophy. Leiden: Brill.

Carter, Warren. 2000. Matthew and the Margins. Maryknoll: Orbis.

Clark, Anna. 2007. Divine Qualities: Cult and Community in Republican Rome. Oxford: Oxford University Press.

Cole, Susan Guettel. 2004. Landscapes, Gender, and Ritual Space: The Ancient Greek Experience. Berkeley: University of California Press.

Coon, Lynda L. 1997. Sacred Fictions: Holy Women and Hagiography in Late Antiquity. Philadelphia: University of Pennsylvania Press.

DeConick, April D. 2005. Recovering the Original Gospel of Thomas: A History of the Gospel and Its Growth. London: T\&T Clark. 2006. The Original Gospel of Thomas in Translation. London: T\&T Clark.

Dillon, Richard J. 1991. Ravens, Lilies, and the Kingdom of God (Matthew 6:25-33/ Luke 12:22-31. CBQ 53(4):605-627.

Elsner, Jaś. 2007. Roman Eyes: Visuality and Subjectivity in Art and Text. Princeton: Princeton University Press.

Fitch, John G. 1987. Seneca's Hercules Furens: A Critical Text with Introduction and Commentary. Ithaca: Cornell University Press.

Fricker, Denis. 2004. Quand Jésus parle au masculine-féminin. Paris: J. Gabalda [Études bibliques].

Gathercole, Thomas. 2014. The Gospel of Thomas: Introduction and Commentary. Leiden: Brill.

Glasson, T. Francis. 1962. Carding and Spinning: Oxyrhynchus Papyrus No. 655. JTS 13(2):331-332.

Gundry, Robert. 2002. Spinning the Lilies and Unravelling the Ravens: An Alternative Reading of Q 12.22b-31 and P. Oxy. 655. NTS 48(2):159-180.

Hachlili, Rachel. 2005. Jewish Funerary Customs, Practices and Rites in the Second Temple Period. Leiden: Brill.

Hersh, Karen K. 2010. The Roman Wedding: Ritual and Meaning in Antiquity. Cambridge: Cambridge University Press.

Jacobs-Malina, Diane. 1993. Beyond Patriarchy: Images of Family in Jesus. Mahweh, NJ: Paulist Press.

Johnson, Lee A., and Robert C. Tannehill. 2010. Lilies Do Not Spin: A Challenge to Female Social Norms. NTS 56(4):475-490.

Jongkind, Dirk. 2006. "The Lilies of the Field" Reconsidered: "Codex Sinaiticus" and the Gospel of Thomas. NovT 48(3):209-216.

Klein, Hans. 2006. Das Lukasevangelium. Göttingen: Vandenhoeck \& Ruprecht.

Kloppenborg, John S. 2000. Excavating Q. Minneapolis: Fortress.

Luz, Ulrich. 1985. Das Evangelium nach Matthäus. Zürich: Benziger; NeukirchenVluyn: Neukirchener Verlag. 
Mattingly, Harold. 1937. The Roman "Virtues." HTR 30(2):103-117.

McGinn, Thomas A. 2004. The Economy of Prostitution in the Roman World: A Study of Social History and the Brothel. Ann Arbor: University of Michigan Press.

Mealand, David L. 1980. "Paradisial" Elements in Jesus' Teaching. Pages 179-184 in Studia Biblica 1978, II: Papers on the Gospels. Edited by Elizabeth A. Livingstone. Sheffield: Sheffield Academic [JSNTSup 2].

Momigliano, Arnaldo. 1987. On Pagans, Jews, and Christians. Middletown, CT: Wesleyan University Press.

Moses, Diana C. 1993. Livy's Lucretia and the Validity of Coerced Consent in Roman Law. Pages 38-83 in Consent and Coercion to Sex and Marriage in Ancient and Medieval Societies. Edited by Angeliki E. Laiou. Washington, DC: Dumbarton Oaks.

O'Connor, Kathleen. 1990. The Wisdom Literature. Collegeville: Liturgical Press.

Petty-Fitzmaurice, William Thomas (Lord Kerry). 1830. An Essay upon the Influence of the Translation of the Bible upon English Literature. Cambridge: B. Bridges.

Peskowitz, Miriam B. 1997. Spinning Fantasies: Rabbis, Gender, and History. Berkeley: University of California Press.

Popkin, Maggie L. 2016. The Architecture of the Roman Triumph: Monuments, Memory, and Identity. Cambridge: Cambridge University Press.

Porter, Stanley E. 2001. P. Oxy. 655 and James Robinson's Proposals for Q: Brief Points of Clarification. JTS 52(1): 84-92.

Robinson, J. M., and C. Heil. 2001. The Lilies of the Field: Saying 36 of the Gospel of Thomas and Secondary Accretions in Q 12.22b-31. NTS 47(1):1-25.

Robinson, James M. 2005. The Sayings Gospel Q: Collected Essays. Leuven: Leuven University Press \& Peeters.

Robinson, James M., Paul Hoffmann, and John S. Kloppenborg, eds. 2002. The Sayings Gospel $Q$ in Greek and English with Parallels from the Gospels of Mark and Thomas. Minneapolis: Fortress [CBET 30].

Rufus, Musonius. 2005. Fragment: That Women Too Should Study Philosophy. Pages 50-54 in Women's Life in Greece and Rome: A Source Book in Translation. 3d ed. Edited by Mary R. Lefkowitz and Maureen B. Fant. Baltimore: Johns Hopkins University Press.

Schottroff, Luise. 1995. Itinerant Prophetesses: A Feminist Analysis of the Sayings Source Q. Pages 347-360 in The Gospel behind the Gospels: Current Studies on $Q$. Edited by Ronald A. Piper. Leiden: Brill [NovTSup 75].

Vermeule, C. C. 1957. Herakles Crowning Himself: New Greek Statuary Types and Their Place in Hellenistic and Roman Art. JHS 77:283-299.

Vernant, Jean-Pierre. 1989. The Cuisine of Sacrifice Among the Greeks. Translated by Paula Wissing. Chicago: University of Chicago Press.

Wallace-Hadrill, Andrew. 1981. The Emperor and His Virtues. Historia: Zeitschrift für Alte Geschichte 30(3):298-323.

\section{janelle@uchicago.edu}

Swift Hall, 1025 E 58th St, Chicago, IL 60637, USA 